\title{
UČINAK UZORKOVANJA KRVI NA KONCENTRACIJU HEMOGLOBINA U HOSPITALIZIRANIH BOLESNIKA
}

\author{
Ivona Margeta ${ }^{1}$, Mirjana Vasilj ${ }^{2}$, Vedrana Gačić ${ }^{2}$, Olivera Perić \\ ${ }^{1}$ Transfuzijski centar, Sveučilišna klinička bolnica Mostar \\ ${ }^{2}$ Klinika za unutarnje bolesti sa centrom za dijalizu, Sveučilišna klinička bolnica Mostar \\ ${ }^{3}$ Klinika za Ginekologiju i porodništvo, Sveučilišna klinička bolnica Mostar, 88000 Mostar, Bosna i Hercegovina \\ Rad je primljen 17.01.2019. Rad je recenziran 01.02.2019. Rad je prihvaćen 09.04.2019.
}

\section{SAŽETAK}

UVOD: Anemija je stanje koje je definirano smanjenim brojem crvenih krvnih stanica u cirkulaciji i/ili smanjenom količinom hemoglobina. Anemije stečene u bolnici su stanja koja se razvijaju u hospitaliziranih bolesnika s prethodno normalnom koncentracijom hemoglobina te su povezane s lošijom prognozom za bolesnike i povećanim iskorištavanjem bolničkih resursa. Hospitaliziranim se osobama gotovo svakodnevno potražuju laboratorijski nalazi, a dnevna količina izvađene krvi iznosi oko $12 \mathrm{~mL}$. Ovakav gubitak bi normalna koštana srž nadomjestila, međutim u bolesnika s različitim bolestima taj nadomještaj može biti smanjen te se povećava mogućnost razvoja anemije. Reed Miller je u svom radu dokazao da je smanjenje koncentracije hemoglobina u korelaciji s dužinom hospitalizacije.

CILJ:Cilj ovog istraživanja je ispitati učinak uzrokovanja krvi na koncentraciju hemoglobina u hospitaliziranih bolesnika. METODE:Ispitanici su osobe muškog i ženskog spola $(\mathrm{N}=100)$, stariji od 18 godina, različite životne dobi hospitalizirani u Klinici za unutarnje bolesti s centrom za dijalizu Sveučilišne kliničke bolnice Mostar u razdoblju od 01.01.2016. do 01.05.2016. čiji su podatci bili dostupni u Bolničkom Informativnom Sustavu. Izabrani su metodom probira vodeći računa o definiranim uključnim/isključnim kriterijima.

REZULTATI: Od ukupnog broja ispitanika 54\% (54) su muškarci, a 46\% (46) žene. Prosječna dob ispitanika je 68 godina. Prosječna količina uzorkovane krvi je 61,9 mL, a prosječan boj uzorkovanje je 12,4. Najčešće korištena epruveta je od 7,5 mL. Rezultati ovog istraživanja pokazali su da postoji korelacija između broja uzorkovanja krvi za pretrage i pada koncentarcije Hgb, odnosno vrijednosti Erc i Hct. Nije utvrđen utjecaj spola na razliku u koncentraciji Hgb na početku i na kraju hospitalizacije.

ZAKLJUČAK: Učestalo uzorkovanje krvi za različite pretrage te veća količina krvi u mL može dovesti do pada koncentracije Hgb kao i različitog stupnja anemije.

Ključne riječi: hemoglobin, uzorkovanje krvi, hospitalizacija, bolesnici.

Osoba za razmjenu informacija: Ivona Margeta

E-mail: i.knezevic.mo@gmail.com

Olivera Perić

E-mail: olivera.peric@fzs.sum.ba

\section{UVOD}

Anemija je stanje koje je definirano smanjenim brojem crvenih krvnih stanica (eritrocita) u cirkulaciji i/ili smanjenom količinom hemoglobina(1). Javljaju se kod oba spola te kod svih dobnih skupina. Anemija se kod mnogih ljudi razvija neprimjetno, a njeni simptomi mogu biti prilično nespecifični. Simptomi 
su kod gotovo svih anemija podjednaki, bez obzira na uzrok i vrstu. Simptomi će biti izraženiji kada anemija nastaje naglo (akutno krvarenje ili akutna hemoliza), nego kada se razvija postupno tijekom više mjeseci ili godina. Najčešće se pacijenti koji imaju razvijenu anemiju žale na opći osjećaj slabosti, glavobolju, pospanost, razdražljivosti, omaglicu i druge nespecifične simptome. Izrazitiji simptomi anemije zapažaju se kad se koncentracija hemoglobina smanji na manje od 80-90 g/L (2).Anemije stečene u bolnici (HAA; od engl. hospital-acquired anemia) su stanja koja se razvijaju u hospitaliziranih bolesnika s prethodno normalnom koncentracijom hemoglobina (3). HAA su stanja povezana s lošijom prognozom za bolesnike i povećanim iskorištavanjem bolničkih resursa (4).Postojanje anemija utvrđuje se uz pomoć laboratorijske analize krvne slike (KS). Za određivanje vrste anemije korisni su različiti podatci dobiveni laboratorijskom analizom krvi, kao što su: koncentracija hemoglobina i hematokrita, stanični indeksi (MCV - prosječni stanični volumen; $\mathrm{MCHC}$ - prosječna stanična koncentracija hemoglobina), broj retikulocita, serumski feritin, razina željeza uz ukupnu sposobnost vezanja željeza (TIBC- engl. "total iron binding capacity"), razina vitamina B12 i folne kiseline u serumu, ukupni bilirubin i direktni bilirubin, haptoglobin i laktat dehidrogenaza (LDH) (5).Dva su temeljna pristupa pri klasifikacija anemija, jedan je kinetički i nastoji utvrditi mehanizam nastanka anemije, a drugi je morfološki pristup koji dijeli anemije s obzirom na veličinu srednjeg volumena eritrocita (MCV) i retikulocitnog odgovora. Kinetičkim pristupom anemije se po nastanku dijele na tri neovisna mehanizma: poremećeno stvaranje eritrocita, ubrzano propadanje eritrocita, te povećan gubitak eritrocita.Morfološki pristup podjele anemija se temelji na veličini eritrocita te se mogu podijeliti na tri skupine: mikrocitne, normocitne i makrocitne anemije(6).Različiti čimbenici i pridružena stanja utječu na anemiju. Neki utječu na razvoj same bolesti, a neki istu pogoršavaju.Čimbenici rizika za anemiju su: prehrana s manjkom vitamina, gastrointestinalne bolesti, menstruacija, trudnoća, kronične bolesti, pozitivna obiteljska anamneza te osobe starije od 65. godina.Neka od stanja koja utječu na laboratorijske parametre u krvnoj slici su: visoka tjelesna temperatura, hiperhidracija ili dehidracija.Visoka tjelesna temperatura $\left(>39^{\circ} \mathrm{C}\right)$ utječe na lance aminokiselina što za posljedicu ima raspadanje molekula hemoglobina (7). Raspad molekula hemoglobina dovodi do smanjenog broja crvenih krvnih stranica (eritrocita) što se u krvnoj slici može očitovati kao anemija. S druge strane, povišena tjelesna temperatura uz smanjen unos tekućine uzrokuje dehidraciju što ima za posljedicu povećanje Hct te u krvnoj slici prividno povećane vrijednosti $\mathrm{E}$ i $\mathrm{Hb}$ (uslijed smanjenog volumena plazme).Hiperhidracija utječe na razinu hematokrita u krvi time što povećava volumen plazme što $\mathrm{u}$ konačnici dovodi do pada razine hematokrita u KS dok dehidracija djeluje suprotno (8). Reed Miller je u svom radu dokazao da je smanjenje koncentracije hemoglobina u korelaciji s dužinom hospitalizacije (9). Hospitaliziranim se osobama gotovo svakodnevno potražuju laboratorijski nalazi, a dnevna količina izvađene krvi iznosi oko $12 \mathrm{~mL}$. Ovakav gubitak bi normalna koštana srž nadomjestila, međutim u bolesnika $s$ različitim bolestima taj nadomještaj može biti smanjen te se povećava mogućnost razvoja anemije (4). Neonatološki, gerijatrijski pacijenti, osobe s nižom tjelesnom masom ili one s malnutricijom, kardiološki bolesnici, osobe koje boluju od malignih oboljenja, šećerne bolesti, bubrežnog zatajenja ili drugih kroničnih bolesti skloni su bržem razvoju anemija $(10,11)$. Neka istraživanja na osobama s infarktom miokarda (iako dijagnoza nije u izravnoj vezi s nastankom anemije ukoliko se isključe postupci poput koronarografije) pokazala su da jedna od pet osoba tijekom boravka u bolnici razvije anemiju (8). Poznato je da se bolesnici u jedinicama intenzivnog liječenja, bolesnici koji se liječe od malignih oboljenja kao i nakon operativnih zahvata sporije oporavljaju ukoliko imaju anemiju (12-14). Prilikom dijagnosticiranja anemija i utvrđivanja uzroka dobro je imati na umu utjecaj uzorkovanja krvi na razinu hemoglobina i razvoj anemije (15). Krvni uzorci potrebni su za obavljanje laboratorijskih pretraga i dio su bolničke svakodnevnice. Kao jednostavna, a izrazito korisna metoda koristi se često, prema nekim istraživanjima čak i više no što je potrebno (16). 
Ovisno o vrsti pretrage, koristi se više vrsta standardiziranih epruveta koje imaju čepove kodirane po bojama. Boja čepa označava aditive za krv koji se nalaze unutar epruvete. Aditivi su kemijski spojevi koji služe za očuvanje uzorka prilikom laboratorijskih postupaka.Aditivi koji se često koriste su antikoagulansi poput ETDA (etilendiamintetraoctena kiselina), natrijev citrat i heparin. Neke epruvete sadrže gel čija je gustoća razine između krvnih zrnaca i seruma. Epruvete se također razlikuju po zapremini, od 1 do $10 \mathrm{~mL}$ (17). Poznato je da se u laboratorije dostavlja prosječno $2,76 \mathrm{~mL}$ više nego je instrumentima potrebno za očitavanje testova kompletne krvne slike (KKS) te $1,75 \mathrm{~mL}$ više od potrebnog za očitavanje testova na elektrolite (18). Također je poznato da za svakih $100 \mathrm{~mL}$ izvađene krvi koncentracija hemoglobina prosječno pada za $0,7 \mathrm{~g} / \mathrm{dL}$ (19). Cilj ovog istraživanja je ispitati učinak uzrokovanja krvi na koncentraciju hemoglobina u hospitaliziranih bolesnika.

Tablica 1. Prikaz osnovnih hematološki parametara u referentnim vrijednostima (5).

\begin{tabular}{|c|c|c|}
\hline \multirow[t]{2}{*}{ Erc } & \multirow[t]{2}{*}{ Eritrociti } & 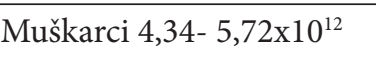 \\
\hline & & $3,86-5,08 \times 10^{12}$ \\
\hline \multirow[t]{2}{*}{$\mathrm{Hgb}$} & \multirow[t]{2}{*}{ Hemoglobin } & \multirow{2}{*}{$\begin{array}{ll}\text { Muškarci } & 138-175 \mathrm{~g} / \mathrm{L} \\
\text { Žene } & 119-157 \mathrm{~g} / \mathrm{L}\end{array}$} \\
\hline & & \\
\hline \multirow[t]{2}{*}{ Htc } & Hematokrit (re- & Muškarci 0,415-0,530 L/L \\
\hline & $\begin{array}{l}\text { lativni volumen } \\
\text { eritrocita) }\end{array}$ & $0,356-0,470 \mathrm{~L} / \mathrm{L}$ \\
\hline \multirow[t]{2}{*}{$\mathrm{MCV}$} & Prosječni volu- & \\
\hline & men eritrocita & $83,0-97,2 \mathrm{Fl}$ \\
\hline \multirow[t]{2}{*}{$\mathrm{MCH}$} & Prosječni sadržaj & Muškarci i žene \\
\hline & $\begin{array}{l}\text { hemoglobina } \mathrm{u} \\
\text { eritrocitu }\end{array}$ & $27,4-33,9 \mathrm{pg}$ \\
\hline $\mathrm{MCHC}$ & $\begin{array}{l}\text { Prosječna kon- } \\
\text { centracija Hb u } 1 \\
\text { L eritrocita }\end{array}$ & $\begin{array}{l}\text { Muškarci i žene } \\
320-345 \text { g/L }\end{array}$ \\
\hline RDW & $\begin{array}{l}\text { Raspodjela eri- } \\
\text { trocita po volu- } \\
\text { menu }\end{array}$ & $\begin{array}{l}\text { Muškarci i žene } \\
9,0-15,0 \%\end{array}$ \\
\hline Rtc & Retikulociti & $\begin{array}{l}\text { Muškarci i žene } \\
22-97 \times 10^{9}\end{array}$ \\
\hline
\end{tabular}

\section{ISPITANICI I METODE}

\section{ISPITANICI}

Istraživanje je provedeno u Sveučilišnoj kliničkoj bolnici Mostar (SKB Mostar).

Uzorak je prikupljen retrogradno, a obuhvaćeni su bolesnici hospitalizirani u razdoblju od 01.01. do 01.05.2016. koji su zadovoljavali uključne kriterije. Ispitanici su osobe muškog i ženskog spola, stariji od 18 godina, različite životne dobi hospitalizirani u Klinici za unutarnje bolesti s centrom za dijalizu SKB Mostar čiji su podatci bili dostupni u Bolničkom Informativnom Sustavu (BIS-u). Izabrani su metodom probira vodeći računa o definiranim uključnim/isključnim kriterijima. Retrospektivno iz medicinske dokumentacije prikupljeni su ciljani podatci: spol i dob ispitanika, dužina hospitalizacije, ulazna i izlazna razina hemoglobina, hematokrita, eritrocita, MCV-a, broj uzoraka krvi za različite pretrage, korištene epruvete, ukupna količina uzorkovane krvi.

\section{METODE}

Podatci su prikupljeni pomoću bolničkog računalnog sustava "BIS-a", na temelju uključnih i isključnih kriterija.Ciljani parametri su izvučeni iz medicinske dokumetacije koja je nastala tijekom hospitalizacije bolesnika. $\mathrm{Na}$ osnovi prikupljanih vrijednosti, metodama statističke analize testirani su hipoteza i ciljevi istraživanja. Spol, dob, dani hospitalizacije, vrijednosti ulaznog i izlaznog hemoglobina, hematokrita, eritrocita i MCV-a, ukupan broj uzorkovanja krvi, korištene epruvete, ukupan broj mililitara uneseni su u Microsoft Excel(inačica Office 2007, Microsoft Corporation, Redmond, WA, SAD) tablicu. Kriterij isključivanja je bila dužina hospitalizacije kraća od 3 dana ili duža od 4 tjedna, liječenje intenzivnom diuretskom terapijom, dehidrirani bolesnici ili primjena hiperhidracije u sklopu liječenja, bolesnici u kojih je proveden postupak hemodijalize, razlog hospitalizacije aktivno krvarenje ili potreba za primjenom krvnih pripravaka, bolesnici sa febrilitetom iznad $38^{\circ} \mathrm{C}$, ženske osobe koje imaju menstrualno krvarenje za vrijeme hospitalizacije. Svi navedeni kriteriji, kao sto je opisano 
u uvodu, imaju ili učinak na krvnu sliku ili direktno na razvoj anemije. Prilikom prikupljanja podataka stavljen je veliki naglasak na privatnost pacijenata, te strogo poštivanje etičkih i bioetičkih normi. Istraživanje je odobreno od strane predstojnice Klinike za unutarnje bolesti SKB Mostar.

\section{STATISTIČKA ANALIZA}

Dobiveni rezultati su obrađeni pomoću deskriptivnih, te neparametrijskih i parametrijskih metoda inferencijalne statistike ovisno o distribuciji podataka. Distribucija uzorka za svaku kontinuiranu varijablu i za svaku istraživanu skupinu je testirana Kolmogorov-Smirnovim testom. Kategorijske varijable su prikazane deskriptivno statistički kao frekvencija i postotak dok su kontinuirane varijable prikazivane kao aritmetička sredina i standardna devijacija. Razlike u kategorijskim varijablama testirane su hi kvadrat testom i Fisherovim egzaktnim testom gdje je to bilo potrebno. Razlike među kontinuiranim varijablama su testirane Student t-testom i t-testom za ponavljana mjerenja. Za testiranje povezanosti među kontinuiranim varijablama je korišten Pearsonov test korelacije. Razina vjerojatnosti od $\mathrm{p}<0,05$ se uzela kao statistički značajna.SPSS statistički softver, verzija 17 , je korišten za sve statističke analize (SSPS Inc., Chicago, IL).

\section{REZULTATI}

Ovim istraživanjem obuhvaćeno je razdoblje od 01.01.2016. do 01.05.2016.godine.

Bolesnici koji su obuhvaćeni istraživanjem bili su oba spola, prosječne starosti od 68 godina. Hospitalizirani su prosječno 11 dana. Socio demografske karakteristike ispitanika prikazane su u Tablici 3.
Tablica 3. Prikaz socio demografskih karakteristika ispitanika

\begin{tabular}{|c|c|c|}
\hline \multicolumn{2}{|c|}{$\begin{array}{l}\text { SOCIO DEMOGRAFSKE } \\
\text { KARAKTERISTIKE ISPITANIKA }\end{array}$} & Broj \\
\hline \multicolumn{2}{|l|}{\begin{tabular}{|l} 
Ukupno \\
\end{tabular}} & 100 \\
\hline \multirow[t]{2}{*}{ Spol } & Ženski & 56 \\
\hline & Muški & 44 \\
\hline \multirow[t]{3}{*}{ Dob } & Najmlađa & 20 \\
\hline & Najstarija & 89 \\
\hline & Prosječna & 68 \\
\hline \multirow{3}{*}{$\begin{array}{l}\text { Dužina trajanja hospitalizacije } \\
\text { u danima }\end{array}$} & Najkraća & 3 \\
\hline & Najduža & 28 \\
\hline & Prosječna & 11 \\
\hline
\end{tabular}

U ispitivanom uzorku je bilo nešto više ispitanika muškog spola, međutim uočena razlika nije bila na razini statističke značajnosti, kao što prikazuje Slika 2.

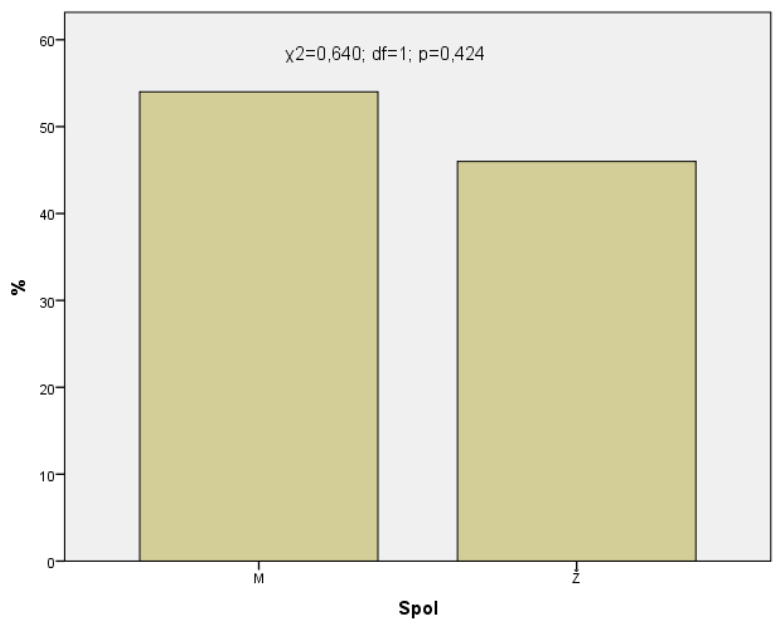

Slika 2. Spolna struktura uzorka.

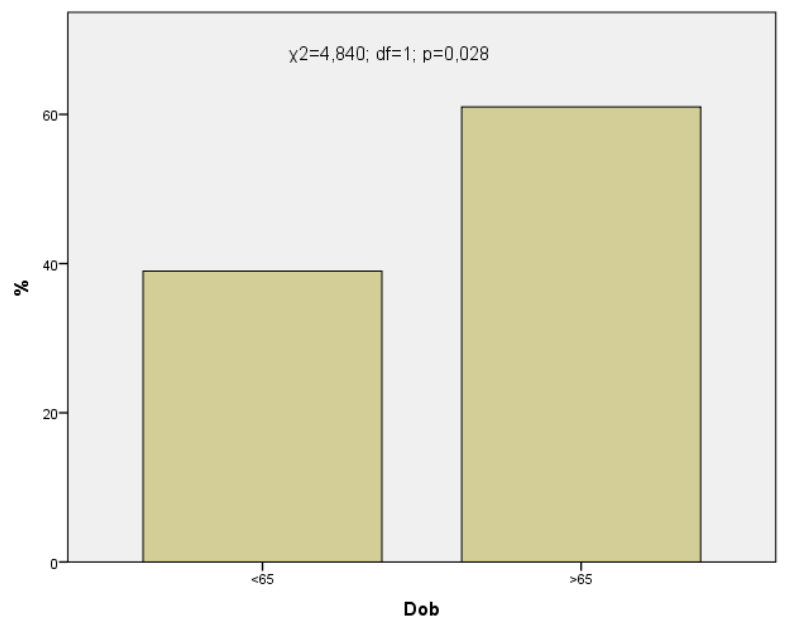

Slika 3. Dobna struktura uzorka. 
U ispitivanom uzorku je bilo značajno više ispitanika starijih od 65 godina, uočena razlika je bila na razini statističke značajnosti, što se vidi iz Slike 3.

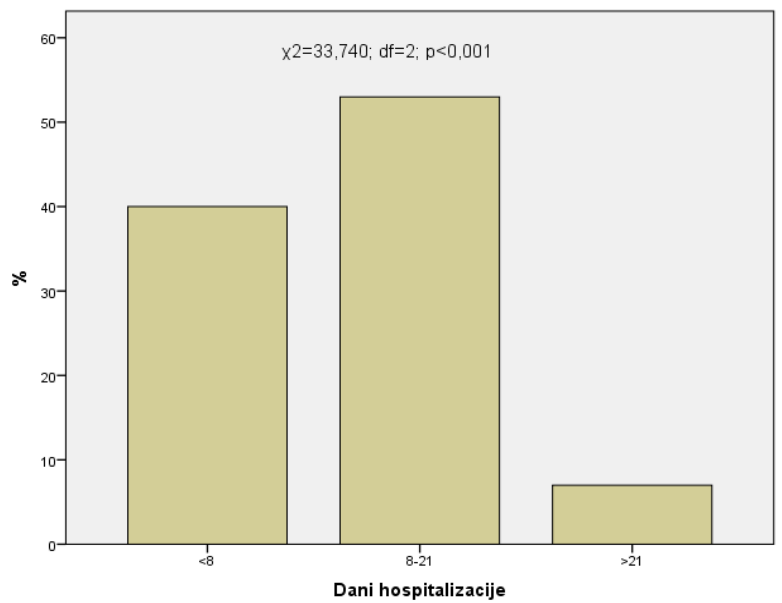

Slika 4. Struktura uzorka prema danima hospitalizacije.

Na Slici 4. Prikazana je struktura uzorka prema danima hospitalizacije. U ispitivanom uzorku najveći udio ispitanika boravio je u bolnici od 8 do 21 dan, a uočena razlika je bila na razini statističke značajnosti. Najmanji broj ispitanika je bio u skupini čija je hospitalizacija trajala duže od 21 dan.

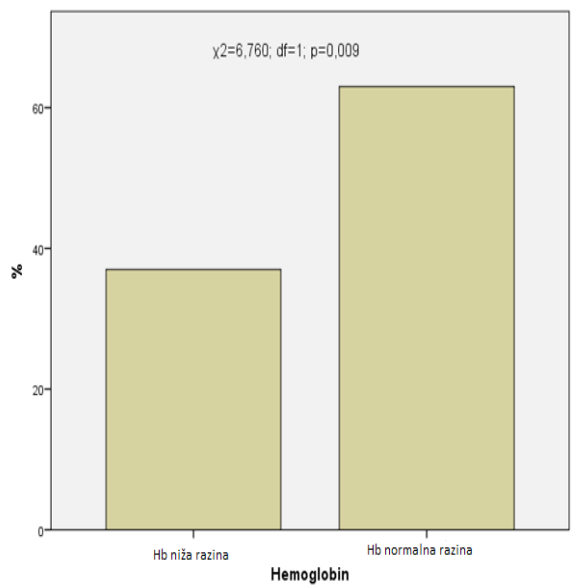

Slika 5. Struktura uzorka prema razini hemoglobina.

$\mathrm{U}$ ispitivanom uzorku najveći udio ispitanika imao je normalnu koncentraciju hemoglobina na početku hospitalizacije dok je značajno manji broj ispitanika na početku hospitalizacije imao nižu koncentraciju hemoglobina od referentnog intervala za određeni spol što prikazuje Slika 5.

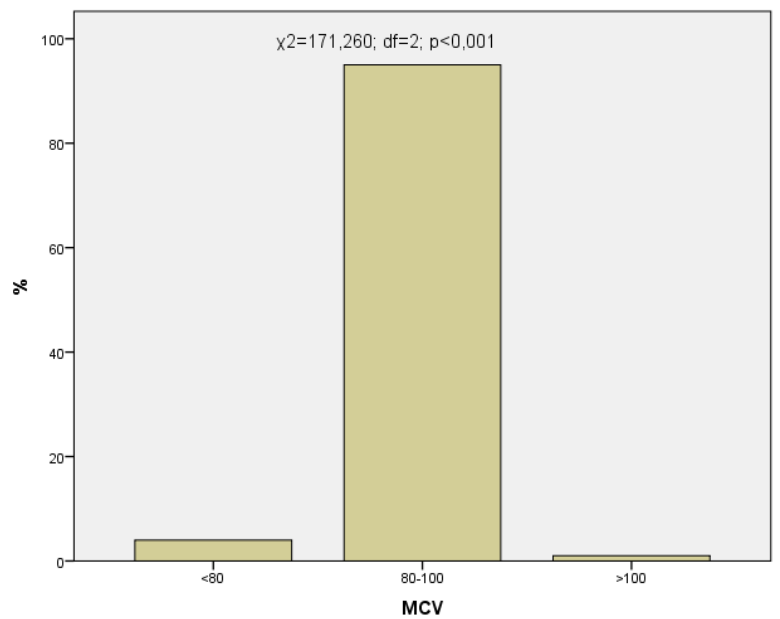

Slika 6. Struktura uzorka prema MCV vrijednostima.

$\mathrm{U}$ ispitivanom uzorku najveći udio ispitanika imao je vrijednosti MCV 80-100, što predstavlja normalnu vrijednost, dok je značajno manje bilo ispitanika s nižim ili višim MCV-om. Uočena razlika je bila na razini statističke značajnost kao što je prikazano na Slici 6.

U Tablici 4. Prikazane su vrijednosti korištene u opisnoj statistici.

Tablica 4. Opisna statistika

\begin{tabular}{|c|c|c|c|c|c|c|}
\hline \multicolumn{7}{|c|}{ Opisna statistika } \\
\hline & & $\mathrm{N}$ & $\begin{array}{l}\text { Mini- } \\
\text { mum }\end{array}$ & $\begin{array}{l}\text { Maxi- } \\
\text { mum }\end{array}$ & \begin{tabular}{|c} 
Srednja \\
vrijed- \\
nost
\end{tabular} & $\begin{array}{c}\text { Std. devi- } \\
\text { jacija }\end{array}$ \\
\hline \multicolumn{2}{|c|}{ Hct1 } & 100 & 0,31 & 0,50 & 0,3992 & 0,03894 \\
\hline \multicolumn{2}{|c|}{ MCV1 } & 100 & 66,70 & 100,00 & 89,7010 & 5,62454 \\
\hline \multicolumn{2}{|c|}{ Erc1 } & 100 & 3,46 & 5,47 & 4,4622 & 0,45451 \\
\hline \multicolumn{2}{|c|}{ Hct2 } & 100 & 0,00 & 0,48 & 0,3799 & 0,05700 \\
\hline \multicolumn{2}{|c|}{ MCV2 } & 100 &, 00 & 102,70 & 89,4720 & 10,60029 \\
\hline \multicolumn{2}{|c|}{ Erc2 } & 100 & 2,93 & 5,36 & 4,2549 & 0,50624 \\
\hline \multicolumn{2}{|c|}{ delta Hgb } & 100 & -34 & 12 & $-7,03$ & 8,500 \\
\hline \multirow{7}{*}{ 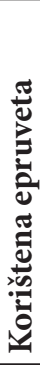 } & $2 \mathrm{~mL}$ & 76 & 1 & 4 & 1,32 & 0,594 \\
\hline & $2,6 \mathrm{~mL}$ & 98 & 1 & 11 & 2,78 & 1,550 \\
\hline & $3 \mathrm{~mL}$ & 69 & 1 & 11 & 2,22 & 1,939 \\
\hline & $4,5 \mathrm{~mL}$ & 68 & 1 & 7 & 2,31 & 1,225 \\
\hline & $7,5 \mathrm{~mL}$ & 100 & 1 & 16 & 5,46 & 2,872 \\
\hline & $1 \mathrm{~mL}$ & 14 & 1 & 8 & 1,79 & 1,888 \\
\hline & $10 \mathrm{~mL}$ & 2 & 1 & 2 & 1,50 & 0,707 \\
\hline \multicolumn{2}{|c|}{$\begin{array}{l}\text { Ukupan broj } \\
\text { uzoraka }\end{array}$} & 100 & 3,0 & 39,0 & 12,450 & 5,9618 \\
\hline \multicolumn{2}{|c|}{ Ukupno mL } & 100 & 14,6 & 183,1 & 61,952 & 29,9701 \\
\hline
\end{tabular}


U ispitivanom uzorku najčešće korištena epruveta bila je od 7,5 mL, pri čemu je najmanji broj uzorkovanja krvi za pretrage tijekom hospitalizacije bio 3 , a najveći 39, srednja vrijednost 12,45 . Najmanja količina uzorkovane krvi tijekom hospitalizacije bila je 14,6 $\mathrm{mL}$, a najveća $183 \mathrm{~mL}$, dok je prosječna bila $61,95 \mathrm{~mL}$. Prosječan pad koncentracije Hgb bio je za $7,03 \mathrm{~g} / \mathrm{dL}$.

Tablica 5. Spolne razlike u istraživanim kliničkim i hematološkim parametrima

\begin{tabular}{|c|c|c|c|c|c|c|}
\hline & \multicolumn{4}{|c|}{ Spol } & \multirow{3}{*}{$\mathrm{T}$} & \multirow{3}{*}{$p$} \\
\hline & \multicolumn{2}{|c|}{ M } & \multicolumn{2}{|c|}{$\check{Z}$} & & \\
\hline & $\overline{\mathrm{X}}$ & SD & $\bar{X}$ & $\mathrm{SD}$ & & \\
\hline Dob & 68,24 & 13,67 & 67,80 & 14,39 & 0,155 & 0,877 \\
\hline $\begin{array}{l}\text { Dani hospi- } \\
\text { talizacije }\end{array}$ & 11,04 & 7,29 & 11,04 & 7,36 & 0,004 & 0,997 \\
\hline Hct1 & 0,41 & 0,05 & 0,39 & 0,03 & 1,720 & 0,089 \\
\hline MCV1 & 90,29 & 5,27 & 89,02 & 5,99 & 1,127 & 0,263 \\
\hline Erc1 & 4,49 & 0,51 & 4,43 & 0,38 & 0,662 & 0,509 \\
\hline Htc2 & 0,38 & 0,07 & 0,38 & 0,03 & 0,639 & 0,525 \\
\hline MCV2 & 89,12 & 13,37 & 89,89 & 6,02 & 0,360 & 0,720 \\
\hline Erc2 & 4,30 & 0,55 & 4,20 & 0,44 & 1,005 & 0,317 \\
\hline delta Hgb & $-6,35$ & 8,98 & $-7,83$ & 7,92 & 0,863 & 0,390 \\
\hline $\begin{array}{l}\text { Ukupan broj } \\
\text { uzoraka }\end{array}$ & 13,11 & 6,97 & 11,67 & 4,45 & 1,204 & 0,231 \\
\hline Ukupno mL & 65,36 & 34,77 & 57,95 & 22,85 & 1,235 & 0,220 \\
\hline
\end{tabular}

Nije bilo značajnih razlika među spolovima u varijablama prikazanim u Tablici 5.

Nije pronađena značajna razlika pada vrijednosti Hct, Hgb, Erc, MCV u odnosu na spol.
Tablica 6. Dobne razlike u istraživanim kliničkim i hematološkim parametrima

\begin{tabular}{|c|c|c|c|c|c|c|}
\hline & \multicolumn{4}{|c|}{ Dob } & \multirow{3}{*}{$\mathrm{T}$} & \multirow{3}{*}{$\mathrm{P}$} \\
\hline & \multicolumn{2}{|c|}{$\leq 65$} & \multicolumn{2}{|c|}{$>65$} & & \\
\hline & $\bar{X}$ & $\mathrm{SD}$ & $\bar{X}$ & $\mathrm{SD}$ & & \\
\hline $\begin{array}{l}\text { Dani hos- } \\
\text { pitalizacije }\end{array}$ & 11,13 & 7,16 & 10,98 & 7,43 & 0,096 & 0,923 \\
\hline Hct1 & 0,42 & 0,04 & 0,39 & 0,04 & 3,634 & $<0,001$ \\
\hline MCV1 & 90,08 & 3,51 & 89,46 & 6,65 & 0,616 & 0,539 \\
\hline Erc1 & 4,61 & 0,43 & 4,37 & 0,45 & 2,740 & 0,007 \\
\hline Hct2 & 0,40 & 0,04 & 0,37 & 0,06 & 2,736 & 0,007 \\
\hline MCV2 & 90,51 & 4,29 & 88,81 & 13,14 & 0,780 & 0,437 \\
\hline Erc2 & 4,42 & 0,49 & 4,15 & 0,49 & 2,662 & 0,009 \\
\hline delta Hgb & 6,72 & 7,86 & 7,23 & 8,94 & 0,292 & 0,771 \\
\hline $\begin{array}{l}\text { Ukupan broj } \\
\text { uzoraka }\end{array}$ & 12,67 & 7,36 & 12,31 & 4,93 & 0,289 & 0,773 \\
\hline Ukupno mL & 64,66 & 35,26 & 60,22 & 26,21 & 0,720 & 0,473 \\
\hline
\end{tabular}

Kako je prikazano u Tablici 6., starija dobna skupina imala je značajno niže vrijednosti Hct i manji broj Erc u oba mjerenja, dok u ostalim prikazanim varijablama nije bilo statistički značajnih razlika. Nije pronađena značajna razlika promjene koncentracije hemoglobina u odnosu na dob.

Tablica 7. Korelacija između promjena hematoloških parametara i uzetih mililitara krvi

\begin{tabular}{|l|l|l|}
\hline \multirow{2}{*}{} & \multicolumn{2}{l|}{ Ukupno $\mathbf{~} L$} \\
\cline { 2 - 3 } & $\mathrm{R}$ & $\mathrm{P}$ \\
\hline$\Delta \mathrm{Hgb}$ & $-0,398$ & $<0,001$ \\
\hline$\Delta \mathrm{Erc}$ & $-0,349$ & $<0,001$ \\
\hline$\Delta \mathrm{MCV}$ & 0,107 & 0,288 \\
\hline$\Delta \mathrm{Hct}$ & $-0,376$ & $<0,001$ \\
\hline
\end{tabular}

Kako je prikazano u Tablici 7., postoji negativna korelacija između promjena $(\Delta) \mathrm{Hgb}$, E i Hct i mililitara i statistički je značajna. Za MCV korelacije nema. 
Tablica 8. Razlike u hematološkim parametrima na početku i na kraju istraživanja

\begin{tabular}{|l|l|l|l|l|}
\hline & \multicolumn{1}{|c|}{$\overline{\mathbf{X}}$} & \multicolumn{1}{c|}{ SD } & \multicolumn{1}{c|}{$\mathbf{t}$} & \multicolumn{1}{c|}{$\mathbf{P}$} \\
\hline MCV1 & 89,72 & 5,64 & $-3,191$ & 0,002 \\
\hline MCV2 & 90,39 & 5,49 & & \\
\hline Erc1 & 4,46 & 0,45 & 7,763 & $<0,001$ \\
\hline Erc2 & 4,25 & 0,51 & & \\
\hline Hgb1 & 135,55 & 15,31 & 8,327 & $<0,001$ \\
\hline Hgb2 & 128,58 & 16,03 & & \\
\hline Hct1 & 0,399 & 0,039 & 7,186 & $<0,001$ \\
\hline Hct2 & 0,383 & 0,042 & & \\
\hline
\end{tabular}

Kako je prikazano u Tablici 8. u drugom mjerenju je bila značajno niža razina Hgb, Erc kao i Hct, dok nije bilo statistički značajnih razlika u vrijednostima MCV.

\section{RASPRAVA}

Ovo istraživanje pokazalo je da postoji korelacija između količine uzorkovane krvi i pada koncentracije hemoglobina, hematokrita i eritrocita. Što je veća količina krvi za različite pretrage, to je veća i razlika između praćenih parametara na početku i na kraju hospitalizacije. Dosadašnja istraživanja su pokazala da su ijatrogenu anemiju uzrokovanu venepunkcijom razvile osobe čiji je prosječni gubitak krvi uzrokovan venepunkcijom veći od $139,3 \mathrm{~mL}$. Blagu anemiju su razvile osobe čiji je prosječni volumen venepunkcije veći od $53.0 \mathrm{~mL}$, a jaču one čiji je volumen veći od $119.1 \mathrm{~mL}$ (20). Rezultati ovog rada ukazuju da je prosječan gubitak krvi uslijed uzorkovanja krvi za različite pretrage bio $61,95 \mathrm{~mL}$ što je usporedivo s rezultatima dosadašnjih istraživanja. Iako su dobiveni rezultati slični, ovdje treba naglasiti i različite uključne i isključne kriterije što u neku ruku daje prednost ovom istraživanju budući da su izuzeta sva stanja bolesnika (kao npr.bolesnicičija je hospitalizacijakraća od 3 dana ilidulja od 4 tjedna, razloghospitalizacijeaktivnokrvarenjeilipotreba za primjenomkrvnihpripravaka, liječenjeintenzivnomdiuretskomterapijom, dehidriranibolesniciiliprimjenahiperhidracije u sklopuliječenja, bolesnici u kojih je provedenpostupakhemodijalize, bolesnici s febrilitetomiznad $38^{\circ} \mathrm{C}$ ) koja su na bilo koji način mogla utjecati na izlazne parametre. Za MCV nije utvrđena korelacija što je i očekivani rezultat ukoliko se uzme u obzir relativno mali prosječni gubitak krvi od $62 \mathrm{~mL}$, a za promjenu prosječnog volumena eritrocita količina izgubljene krvi bi trebala biti značajno veća osobito u slučaju kada su početne vrijednosti MCV-a normalne kao što je slučaj u većine ispitanika u ovom istraživanju.Dobiveni rezultati potvrđuju hipotezu da učestalouzorkovanjekrvi za pretrage $\mathrm{u}$ hospitaliziranihbolesnikarezultirasmanjenjemkoncentracijehemoglobina.Studija A.C. Salizbury-ja i suradnika u koju je uključeno 57 bolnica iz cijele Amerike, provedena na kardiološkim odjelima, je pokazala da se najčešće koriste epruvete za acidobazni status (ABS- $1 \mathrm{~mL}$ ). $U$ mom istraživanju najčešće je korištena epruveta od 7,5 mL. Iako se može pretpostaviti da se na Odjelima kardiologije češće potražuje acidobazni status u odnosu na sve odjele Klinike za unutarnje bolesti gdje se potražuju različite biokemijske pretrage, a gdje je i rađeno ovo istraživanje ipak se mora kritički osvrnuti i na činjenicu da je uzorkovanje krvi u nekih ispitanika i više puta ponavljano što može ukazivati na potrebu češćeg praćenja nekih od ispitanika, ali i na mogućnost naknadnog odlučivanja o željenim pretragama. Naime, ponekad rezultati dobivenih pretraga utječu na daljnji slijed indiciranja pretraga, a za to je potreban novi uzorak, budući da se vrlo rijetko u SKB Mostar, što proceduralno, što administrativno, može dobiti naknadno tražena pretraga iz istog uzorka. Ako se tome pridoda i ranije utvrđena količina potrebne krvi za pojedine pretrage (poznato je da se u laboratorije dostavlja prosječno $2,76 \mathrm{~mL}$ više nego je instrumentima potrebno za očitavanje testova kompletne krvne slike (KKS) te $1,75 \mathrm{~mL}$ više od potrebnog za očitavanje testova na elektrolite (18)) te ponekad neracionalno traženje različitih pretraga jasno je da bi se uvođenjem standardiziranih epruveta, kao i mogućnosti da se iz istog uzorka krvi učine i dodatne pretrage mogao značajno smanjiti broj uzorkovanja kao i količina uzete krvi u $\mathrm{mL}$ za različite pretrage tijekom hospitalizacije. Dosadašnji istraživači smatraju da bi se standardizacijom veličine epruveta na $2-5 \mathrm{~mL}$ značajno smanjio ukupni volumen izvađene krvi (21). Isti učinak imala bi i racionalizacija broja uzorkovanja krvi, a nesumnjivo bi imala i utjecaj na zadovoljstvo bolesnika tijekom 
hospitalizacije. U ovom istraživanju nije bilo statistički značajnih promjena koncentracije Hgb u odnosu na učestalost uzorkovanja krvi s obzirom na dob. Ispitanici su za potrebe ovog istraživanja podijeljeni samo $u$ dvije skupine ( $\leq 65$ godina i $>65$ godina). Za ispitivanje utjecaja dobi na pad koncentracije $\mathrm{Hgb} \mathrm{u}$ odnosu na količinu uzorkovbane krvi bilo bi potrebno razdvojiti ispitanike na više dobnih skupina, a samim tim i uzorak bi trebao biti veći zbog moguće disperzije rezultata. U ovom istraživanju nisu razdvojene mlađe dobne skupine gdje bi se teoretski mogli očekivati bolji kompenzatorni mehanizmi, a i dužina hospitalizacije je ograničena upravo zbog toga da bi se izbjegao utjecaj kompenzatornih mehanizama na koncentraciju Hgb stoga je rezultat u skladu s očekivanim. Nije utvrđena statistički značajna razlika promjene koncentracije hemoglobina u odnosu na učestalost uzorkovanja krvi s obzirom na spol što se može tumačiti dijelom i dobnom raspodjelom prema kojoj je za očekivati da je većina osoba ženskog spola u menopauzi (statistički je bilo značajno više ispitanika starijih od 65 godina), a za one mlađe isključni kriterij je bio menstrualno krvarenje za vrijeme hospitalizacije te je i ovaj rezultat u skladu s očekivanim. Budući da nisu pronađena slična istraživanja utjecaja dobi i spola na promjenu koncentracije hemoglobina $u$ odnosu na učestalost uzorkovanja krvi dobivene rezultate nije moguće usporediti s dosadašnjim. $U$ svom radu, Thavendiranathan i suradnici pokazali su da bolesnici s višim vrijednostima hemoglobina/ hematokrita zabilježenim na početku hospitalizacije imaju izrazitiji pad ovih vrijednosti na kraju hospitalizacije (11). Slični rezultati dobiveni su i u ovom istraživanju što se može tumačiti na dva načina: pacijenti s višom ulaznom vrijednošću hemoglobina/ hematokrita će izgubiti više crvenih krvnih stanica (eritrocita) po mL izvađene krvi nego oni s nižom vrijednošću. S druge strane moguće je da i su osobe s višom ulaznom vrijednošću Hgb/Hct zapravo dehidrirane pa da bolničkom rehidracijom dolazi do povećanja volumena plazme pa samim tim i pada koncentracije $\mathrm{Hgb}$, odnosno vrijednosti Hct. Za naše istraživanje drugo obrazloženje bi bilo prihvatiljivo samo u slučaju nepoznatog podatka o stanju hidriranosti na početku hospitalizacije jer su isključene sve osobe koje su u sklopu liječenja hiperhidrirane. Analizom prikupljenih podataka uočeno je da su hospitalizirane osobe starije dobne skupine značajno češće imale niže vrijednosti Hct i $\mathrm{E}$ i na početku i na kraju hospitalizacije što je zapravo očekivani rezultat s obzirom na činjenicu da su stariju dobnu skupinu činili hospitalizirani bolesnici životne dobi $>65$ godina $s$ različitim bolestima.Navedeni rezultati ovog istraživanja usporedivi su s dosadašnjim uz naglasak postojanja različitih uključnih/isključnih kriterija, kao i različitih promatranih ulaznih i izlaznih vrijednosti i korelacija.

\section{ZAKLJUČAK}

Učestalo uzorkovanje krvi za različite pretrage te veća količina krvi u mL može dovesti do pada koncentracije Hgb kao i različitog stupnja anemije.Ne postoji statistički značajna razlika promjene koncentracije hemoglobina, $\mathrm{u}$ odnosu na učestalost uzorkovanja krvi s obzirom dobne skupine $(\mathrm{p}=0,771)$, te s obzirom na spol $(\mathrm{p}=0,390)$. 


\section{LITERATURA:}

1. Vrhovac B, Jakšić B, Reiner Ž, Vucelić B. Interna medicina. U: Branimir J, Damir N. Krvotvorni sustav. Medicinska naklada, Ljevak. 2008;9:9312.

2. Hozo I, et all. Internistička ptopedeutika. U: Lazić D. Hematološka propedeutika. Hrvatsko gastroenterološko društvo-ogranak Split, 2013.

3. Ahmed AH. Prevention and Menagement of hospital-acquired anemia. Hosp Med Clin 3. 2014;e71-84.

4. Koch CG, LI L, Hixson ED et al. Hospital acquired anemia: Prevalence, outcomes, and healthcare implications. J Hosp Med 2013;8;506-12.

5. Lin JC, Strauss RG, Kulhavy JC, et al. Phlebotomy overdraw int he neonatal intensive care nursery. Pediatrics. 2000;106:E19.

6. Labar B,Hauptmann E, et all. Hematologija. U: Anemije. Školska knjiga, Zagreb. 2007;11:10259.

7. Stadler AM, Digel I, Artmann GM, Embs JP, et al.Hemoglobin Dynamics in Red Blood Cells: Correlation to Body Temperature. Biophys J 2008;95:5449-5461.

8. "High and Low Hematocrit Levels" http:// the-healthcare.org/symptoms-and-diagnosis/ lab-results/high-and-low-hematocrit-levels/. Pristupljeno 20. Lipnja 2018.

9. Provan D, Singer CRJ, Baglin T, et all. Oxford handbook of Clinical Haematology. Oxford University Press, Inc., New York. 2004.

10. Reed M. Drawing Too Much Blood May Increase Anemia Risks. Medscape. 2011.

11. Thavendiranathan P, Bagai A, Ebidia A, Detsky AS, Choudhry NK. Do blood tests cause anemia in hospitalized patients? The effect of diagnostic phlebotomy on hemoglobin and hematocrit levels. J Gen Intern Med 2005;20:520-524.
12. Shailaja JH, Tyler JA, Timothy RW, et al. Anemia in Critical Illness Insights into Etiology, Consequences, and Management. CI. Epub. 2012.

13. Partridge J, Harari D,Gossage J, DhesiJ. Anaemia in the older surgical patient:a review of prevalence, causes, implications and management.J R Soc Med. 2013;106:269-277.

14. Radziwon P, Krzakowski M, Kalinka-Warzocha E, et al. Anaemia in cancer patients - Expert Group recommendations. Oncology in Clinical Practice 2017;13-5:202-210.

15. Eaton KP, Levy K, Soong K, at al.Evidace-Based Guidlines to Eliminate Repetitive Laboratory Testing. Arch Intern Med. 2017;177:1833-1839.

16. Dale JC, Purett SK. Phlebotomy-a minimalist approach. Mayo Clin Poc. 1993:68:249-255.

17. "Vajkutaner sistem za krvne pretrage" https:// ivamilosevic5.wordpress.com/2016/01/17/vakutajner-sistem-za-krvne-analize/. Pristupljeno 15. Lipnja 2018.

18. Dale JC, Ruby SG. Specimen collection volumes for laboratory tests. Arch Pathol Lab Med. 2003; $127: 162-168$

19. Lutz C, Cho HJ. Are we cousing anemia by ordering unnesessary blood tests? Clevelad Clinic Journal of Medicine. 2016;83:496-7.

20. Salizbury AC, Reid KJ, Alexander KP, et al. Diagnostic blood loss from phlebotomy and hospital-acured anemia during acute myocardial infraction. Arch inrern Med. 2011;171:1646-53.

21. Stefanini M. Iatrogenic anemia (can it be prevented?). J Thromb Haemost. 2014;12:1591. 


\title{
EFFECT OF BLOOD SAMPLING ON HAEMOGLOBIN CONCENTRATIONS IN HOSPITALIZED PATIENTS
}

\author{
Ivona Margeta ${ }^{1}$, Mirjana Vasilj², Vedrana Gačić ${ }^{2}$, Olivera Perić ${ }^{3}$ \\ ${ }^{1}$ Tranfusion center, University Clinical Hospital Mostar \\ ${ }^{2}$ Internal Medicine Clinic with Dialysis Center, University Clinical Hospital Mostar \\ ${ }^{3}$ Deparment of Gynecology and Obstetrics,University Clinical Hospital Mostar, 88000 Mostar, \\ Bosnia \& Herzegovina
}

\begin{abstract}
INTRODUCTION: Anemia is a condition defined by a reduced number of red blood cells in circulation and/or decreased hemoglobin levels. Anemia acquired in hospitals is a condition developed in hospitalized patients with previously normal hemoglobin concentrations and is associated with poor prognosis for patients and increased exploitation of hospitals resources. Laboratory findings are requested daily in hospitalized patients and daily amount of withdrawn blood is about $12 \mathrm{ml}$. This kind of loss would be replaced by bone marrow in healthy patients, but in patients with various diseases the replacement may be diminished and thereby increase the risk of developing anemia.In his work, Red Miller proved that the reduction of hemoglobin levels is in correlation with the length of hospitalization.

OBJECTIVE: The objective of this study is to investigate the effect of blood sampling on hemoglobin concentrations in hospitalized patients.

SUBJECTS AND METHODS: The subjects are male and female patients $(\mathrm{N}=100)$, aged 18 and older, hospitalized at the Internal Medicine Clinic with Dialysis Center of the University Clinical Hospital Mostar in the period from January $1^{\text {st }}$ 2016 to May $1^{\text {st }} 2016$ whose data were available in the Hospital Information System. The patients were selected according to the method of screening taking into account the defined inclusion and exclusion criteria.

RESULTS: Out of the total number of respondents, $54 \%$ (54) were men and $46 \%$ (46) were women. The average age of the respondents was 68 years. The average sample size was $61.9 \mathrm{ml}$ and the average number of sampling was 12.4. The most commonly used test tube was $7.5 \mathrm{ml}$. The results of this study show that there is a correlation between the number of blood sampling test and the reduction of hemoglobin levels that is the values of ERC and HCT. There was no effect of gender on differences in hemoglobin concertation at the beginning and end of hospitalization.

CONCLUSION:Frequent blood sampling for different test andincreased amount of blood in ml may lead to a decrease in hemoglobin concentrations and varying degrees of anemia.
\end{abstract}

Key words: hemoglobin, blood sampling, hospitalization, patients

Correspondence: IvonaMargeta

Email: i.knezevic.mo@gmail.com

Olivera Perić

Email: olivera.peric@fzs.sum.ba 